\title{
Diversity and structure of Ephemeroptera, Plecoptera and Trichoptera (Insecta) assemblages from riffles in mountain streams of Central Brazil
}

\author{
Pitágoras C. Bispo ${ }^{1} \&$ Leandro G. Oliveira ${ }^{2}$ \\ ' Laboratório de Biologia Aquática, Departamento de Ciências Biológicas, Faculdade de Ciências e Letras de Assis, \\ Universidade Estadual Paulista. Avenida Dom Antônio 2100, 19806-900 Assis, São Paulo, Brasil. \\ E-mail: pitagoras@assis.unesp.br \\ ${ }^{2}$ Departamento de Biologia Geral, Instituto de Ciências Biológicas, Universidade Federal de Goiás. Campus Samambaia, \\ Caixa Postal 131, 74001-970 Goiânia, Goiás, Brasil. E-mail: lego@icb.ufg.br
}

\begin{abstract}
The diversity and structure of Ephemeroptera, Plecoptera and Trichoptera (EPT) assemblages in streams of Central Brazil (Serra dos Pireneus, Pirenópolis, State of Goiás) was investigated. Abundance data of EPT were obtained in Central-West Brazilian streams in order to evaluate the effect of spatial variability, including the effect of size of the stream and anthropic action, and seasonality (dry and rainy seasons) on faunal diversity and structure. The immatures were collected with circular sieves $(0.5 \mathrm{~mm}$ mesh) during one hour at five collection stations over 14 months. From a spatial point of view, the data showed that anthropic action determined the patterns of diversity whereas the size of streams ( $1^{\text {st }}$ and $3^{\text {rd }}-4^{\text {th }}$ orders) determined the faunistic composition. In addition, environmental seasonality was an important factor for structuring the EPT fauna. KEY WORDS. Aquatic insects; EPT; immatures; lotic environments.
\end{abstract}

\begin{abstract}
RESUMO. Diversidade e estrutura de comunidades de Ephemeroptera, Plecoptera e Trichoptera (Insecta) em riachos de montanha do Brasil Central. A diversidade e a estrutura de comunidades de Ephemeroptera, Plecoptera e Trichoptera (EPT) em riachos do Brasil Central (Serra dos Pireneus, Pirenópolis, Estado de Goiás) foi investigada. Dados de abundância de EPT foram obtidos em trechos de corredeira de riachos do Centro Oeste Brasileiro com o objetivo de avaliar o efeito da variabilidade espacial, incluindo o efeito do tamanho do riacho e da ação antrópica, e da sazonalidade (seca e chuva) sobre a diversidade e a estrutura faunística. Os imaturos foram coletados mensalmente com redes circulares $(0,5 \mathrm{~mm}$ de malhas) por uma hora em cinco pontos de coleta durante 14 meses. Do ponto de vista espacial, os dados do presente trabalho mostraram que a ação antrópica determinou os padrões de diversidade, enquanto que o tamanho dos riachos $\left(1^{\mathrm{a}}\right.$ e $3-4^{\mathrm{a}}$ ordens) determinou a composição faunística. Aliado a isso, a sazonalidade ambiental foi um fator importante para a estruturação da fauna de EPT. PALAVRAS-CHAVE. Ambientes lóticos, EPT; imaturos; insetos aquáticos.
\end{abstract}

The structure of the fauna of aquatic insects in lotic environments is directly related to geomorphology, hydrology, quality of water, quality and availability of food resources, dominant substratum, temperature and dissolved oxygen (VANNOTE et al. 1980, Richards et al. 1993, ZAMORA-MuÑoz et al. 1993, ZAMORAMuñoz \& Alba TerCedor 1996, Bispo et al. 2006). Those characteristics vary in time and space; therefore, it is expected that those variation determine the spatial and temporal alteration of diversity and of structure of fauna in the aquatic communities.

Among the aquatic insects, Ephemeroptera, Plecoptera and Trichoptera, usually known as EPT, comprise a rich assemblage of taxa in low and medium order cobble streams. These organisms are sensitive to environmental perturbations and occur, mainly, in clean and well-oxygenated waters. Due to those characteristics, these organisms are frequently considered as good indicators of water quality (ROSENBERG \& RESH 1993). According to Marchant et al. (1995), patterns found for EPT represent the same patterns found for the macroinvertebrate fauna as a whole; for this reason, studies could be restricted to that fauna. Bispo et al. (2006) have investigated the effect of environmental factors over the distribution of EPT and have concluded that precipitation, stream order and altitude were the main factors that determine distribution and fauna abundance. The present work aimed to evaluate the effect of spatial variation, including the effects of stream size, anthropic action, and seasonality (dry and rainy seasons) over diversity and structure of Ephemeroptera, Plecoptera and Trichoptera assemblages.

Revista Brasileira de Zoologia 24 (2): 283-293, junho 2007 


\section{MATERIAL AND METHODS}

\section{Study area}

The present study was conducted in the basin of the Rio das Almas (Almas River), in Pirenópolis, State of Goiás. The Rio das Almas originates in Serra (mountain chain) dos Pireneus, and its many headwaters are steep streams with stony and sandy bottoms and some pools with leaf debris. These tributaries flow along the western slope of the chain and are part of the hydrographic network of the Amazon Basin.

According to NIMER (1989), the studied region presents a semi-humid tropical climate, with rainy season in summer (marked rainfall between December and February) and dry season in winter (from May to September).

\section{Stations, sampling and taxonomical identifications}

Five collection stations were established: station $1,1^{\text {st }}$ order segment of Córrego do Inferno (Inferno stream); station 2, $3^{\text {rd }}$ order segment of Rio das Almas in Pireneus chain; station 3, $4^{\text {th }}$ order segment of Rio das Almas, in Pireneus chain, inside a country club; station $4,4^{\text {th }}$ order segment of Rio das Almas inside the town; and station 5, Córrego Vagafogo (Vagafogo Stream), a $1^{\text {st }}$ order tributary of Rio das Almas downstream from the town. Those stations were monthly sampled over a period of 14 months (June, 1993 to July, 1994), except station 4, sampled from August, 1993 to July, 1994. For the determination of stream order, Strahler (1957) was followed. During the collections, the following water physical and chemical characteristics were registered: air and water temperature $\left({ }^{\circ} \mathrm{C}\right.$, with an alcohol thermometer), water velocity $\left(\mathrm{m} / \mathrm{s}\right.$, by floater method), flow $\left(\mathrm{m}^{3} / \mathrm{s}\right.$, according to methodology in Lind 1979), electric conductivity ( $\mu \mathrm{S} / \mathrm{cm}$, with a CORNING OS-17 conductivimeter) and hydrogenic potential ( $\mathrm{pH}$, with a CORNING PS-15 meter). Table I shows the characterization of each station. The precipitation of the previous month, according to FleCKER \& FEIFAREK (1994), was used in order to characterize environmental seasonality.

The immatures were collected in riffles through a sampling effort of 1 hour, with circular sieves $(15 \mathrm{~cm}$ diameter and
$0.5 \mathrm{~mm}$ mesh). Later, the material was kept in $80 \%$ alcohol. In laboratory, the EPT immatures were separated and identified to genus, the level possible for the EPT immatures, according to Domínguez et al. (1992) for Ephemeroptera, Benedetto (1974) and Froenlich (1984) for Plecoptera and Angrisano (1995) and Wiggins (1998) for Trichoptera.

\section{Data analysis}

The diversity of the EPT fauna was evaluated through curves of rarefaction and an index of diversity. The rarefaction curves (Hulbert 1971, Simberloff 1972) were computed through Monte Carlo permutations. In order to estimate the number of taxa to $\mathrm{k}$ individuals, $\mathrm{k}$ individuals were randomly taken from the samples and the number of observed taxa was registered. That procedure was repeated 1000 times. The method of rarefaction was utilized to standardize richness for a given number of individuals. In the case of comparison of EPT richness of Pirenópolis with richness of the other two regions (Campos do Jordão and Parque Estadual Intervales, State of São Paulo), data were standardized. For this, only data from two streams of $1^{\text {st }}$ $2^{\text {nd }}$ orders (low order) and two streams of $3^{\text {rd }}-4^{\text {th }}$ orders (medium order) for each of the regions were selected. Considering data from Pirenópolis, the stations 1 and 5 were representative of the $1^{\text {st }}-2^{\text {nd }}$ orders streams, and the stations 2 and 3 were representative of the $3^{\text {rd }}-4^{\text {th }}$ orders streams. Only data related to March, May and November were considered, since collections in one of the regions were done only in those months.

The region of the Pireneus chain presented two well-defined seasons: a rainy and a dry one (Fig. 1). Considering the precipitation of the month previous to the collection (FLECKER \& FeIfareK 1994), it was possible to characterize two periods, a dry (precipitation $<100 \mathrm{~mm}$; June, July, August, September, October and November) and a rainy one (precipitation $>100$ mm; January, February, March, April, May and December). In that sense, data grouped in dry and rainy seasons were used in the analysis of EPT diversity in Pirenópolis. As twice samplings were done in June and July (1993 and 1994), only the samplings of 1994 were considered in the analysis of the dry sea-

Table I. Environmental characterization of the five stations in streams of the Serra dos Pireneus, Pirenópolis.

\begin{tabular}{|c|c|c|c|c|c|}
\hline \multirow{2}{*}{ Paramaters } & \multicolumn{5}{|c|}{ Stations } \\
\hline & 1 & 2 & 3 & 4 & 5 \\
\hline Altitude (m) & 1100 & 780 & 750 & 730 & 710 \\
\hline Order & $1^{\text {st }}$ & $3^{\text {rd }}$ & $4^{\text {th }}$ & $4^{\text {th }}$ & $1^{\text {st }}$ \\
\hline Degree of canopy cover & High & Medium & Sparse & None & High \\
\hline Water temperature $\left({ }^{\circ} \mathrm{C}\right)$ & $18.607 \pm 1.212$ & $19.071 \pm 1.785$ & $20.492 \pm 2.102$ & $20.417 \pm 2.601$ & $20.643 \pm 1.994$ \\
\hline Air temperature $\left({ }^{\circ} \mathrm{C}\right)$ & $20.607 \pm 1.923$ & $21.250 \pm 3.756$ & $22.607 \pm 3.212$ & $22.000 \pm 4.385$ & $22.071 \pm 2.630$ \\
\hline Water velocity $(\mathrm{m} / \mathrm{s})$ & $0.295 \pm 0.084$ & $0.479 \pm 0.140$ & $0.659 \pm 0.248$ & $0.830 \pm 0.250$ & $0.376 \pm 0.134$ \\
\hline Discharge $(\mathrm{m} 3 / \mathrm{s})$ & $0.043 \pm 0.023$ & $0.647 \pm 0.382$ & $0.786 \pm 0.585$ & $3.086 \pm 2.387$ & $0.264 \pm 0.176$ \\
\hline $\mathrm{pH}$ & $7.409 \pm 0.266$ & $8.309 \pm 0.176$ & $8.418 \pm 0.232$ & $8.236 \pm 0.211$ & $7.545 \pm 0.211$ \\
\hline Eletrical conductivity $(\mu \mathrm{S} / \mathrm{cm})$ & $8.636 \pm 5.045$ & $21.364 \pm 5.045$ & $29.454 \pm 7.091$ & $22.274 \pm 4.671$ & $16.818 \pm 4.045$ \\
\hline
\end{tabular}

Revista Brasileira de Zoologia 24 (2): 283-293, junho 2007 


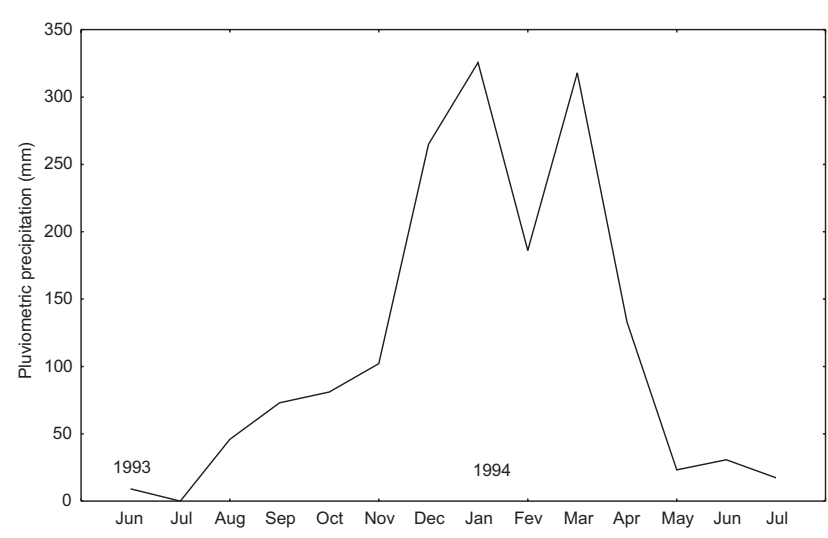

Figure 1. Variation in rainfall (June 1993 to July 1994) for Serra dos Pireneus, Pirenópolis.

son. Therefore, the estimates of diversity and richness were based on samples collected in the dry and in the rainy seasons (each comprising six months of collection) for the five stations. The diversity for each station, considering grouped data for dry and rainy seasons, was calculated utilizing the Diversity
Index of Shannon-Wiener $\left(\mathrm{H}^{\prime}=-\Sigma \mathrm{p}_{\mathrm{i}} \ln \mathrm{p}_{\mathrm{i}}\right)$ and the Eveness Index of Pielou $\left(E=H^{\prime} / \operatorname{lnS}\right)$, where $p_{i}$ is $n_{i} / N, n_{i}$ is the abundance of taxon i, N is total abundance and $\mathrm{S}$ is richness. The standardized richness through the rarefaction method was also calculated for the grouped data. For the Shannon-Wiener index, a t test was done, utilizing Hutcheson's method (MAGURANN 1989) to compare the diversity of the stations among themselves. Due to the problem of multiple comparisons a Bonferroni correction ( $\alpha$ /number of comparisons) was applied in order to obtain the significance of the test (Gotelli \& Ellison 2004).

Temporal and spatial structure of EPT fauna was evaluated through multivariate methods. The matrix was submitted to an ANOSIM (Similarity Analysis) two factors without replication, considering the sources of spatial and temporal variation. The ANOSIM is part of a group of analyses to test whether there are differences in multivariate structures of previously established groups. To ANOSIM two factors without replication, if the site effect is responsible for community changes in consistent way, separate matrices of similarity (among the sites) for each time should show a high concordance. In the same way, if temporal effect is consistent, a high concordance among the matrices of similarity (among the times) for each site should be found. The
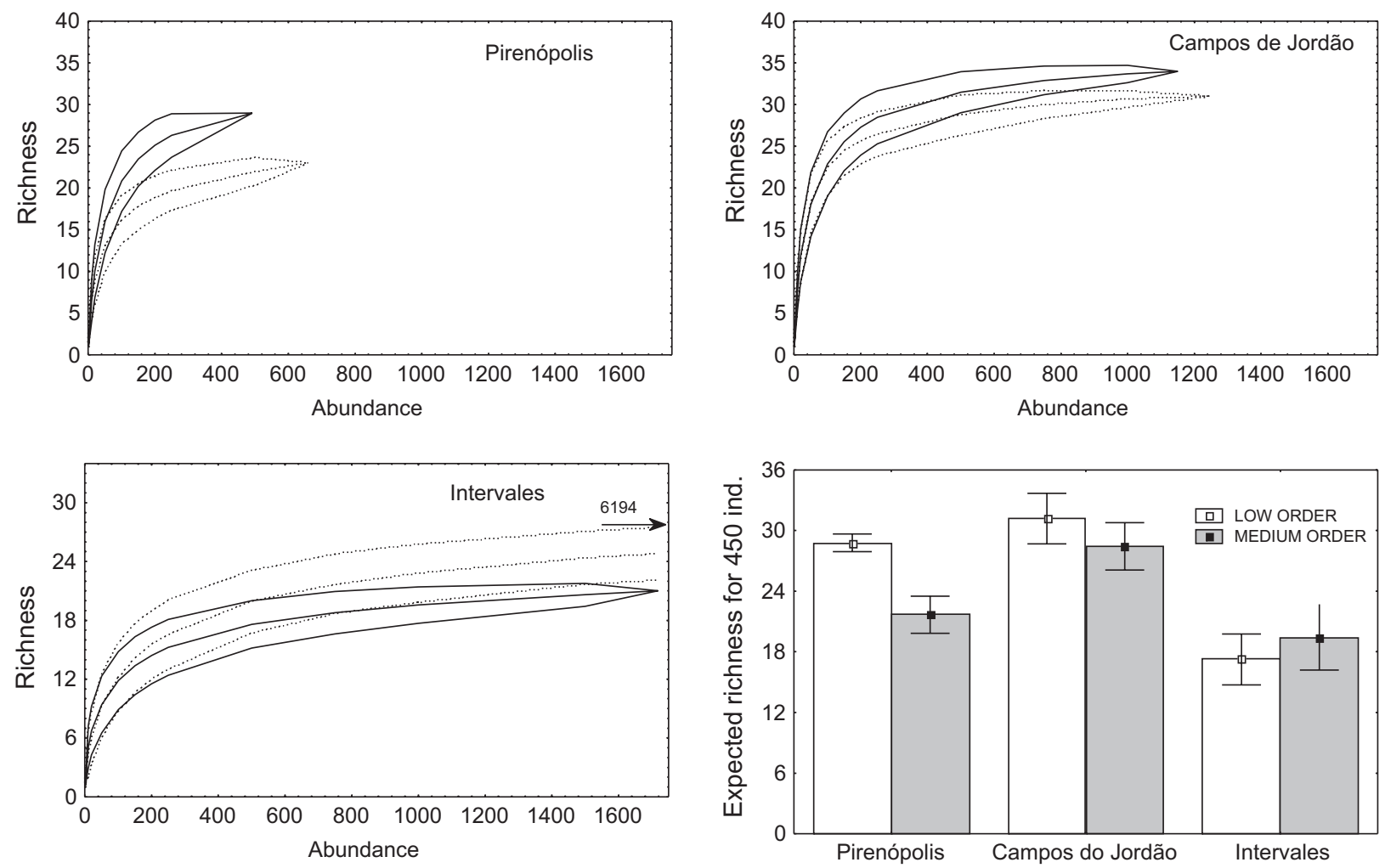

Figure 2. Rarefaction curves of immatures of genera of EPT collected in the regions of Pirenópolis, Campos do Jordão and the Parque Estadual Intervales. In each region, data correspond to four stations ( $21^{\text {st }}-2^{\text {sd }}$ orders and $23^{\text {rd }}-4^{\text {th }}$ orders $)$ and samples collected in March, May and November. Continuous line, low $\left(1^{\text {st }} 2^{\text {sd }}\right)$ order stations; dashed line, medium $\left(3^{\text {rd }}-4^{\text {th }}\right)$ order stations. 
concordance is evaluated by global $\rho$ (Spearman correlation coefficient), which is the average of all pairwise correlations between the matrix of similarity among the sites (or among the times) for each time (or site) (Clarke \& Warwick 1994). The significance is obtained through the Monte Carlo Method. Here the ANOSIM was based on the similarity matrix of Bray-Curtis and 1000 permutations were employed (Clarke \& Warwick 1994). The logarithmized matrix $[\log (\mathrm{x}+1)]$ was submitted to the Detrended Correspondence Analysis (DCA) (GAUCH 1995). The original matrix was submitted to the method of divisive classification TWINSPAN (Two Way Indicator Species Analysis) (GAUCH 1995).

Rarefaction was done through the simulation program Ecosim 5 (Gotelli \& EnTSMigen 2000). The ANOSIM was carried through the program PRIMER 5.0 (CLARKe \& Gorley 2001), the DCA and the TWINSPAN were done through the PCORD 4.0 (MCCune \& MEFFord 1999) program.

\section{RESULTS}

\section{EPT diversity}

The EPT taxa collected in five streams of Serra dos Pireneus are listed in table II. The EPT standardized richness (450 individuals) of Pirenópolis region was intermediate when compared to faunas of other sites (Fig. 2); richness was also greater in sites of $1^{\text {st }}$ order than in sites of $3^{\text {rd }}-4^{\text {th }}$ orders (Fig. 2). It was observed that in the dry season the values of the Shannon-Wiener index were significantly greater in stations 1,2 and 5, and they were smaller in stations 3 and 4 (t test of Hutcheson with correction of Bonferroni) (Fig. 3). In the rainy season, the values of the Shannon-Wiener index had the following sequence: Station $1>$ Station $2>$ Station $3=$ Station $5>$ Station 4 (t test of Hutcheson with correction of Bonferroni) (Fig. 4). The values of eveness varied between 0.74 and 0.78 in the dry season. In the rainy season, eveness varied between 0.65 and 0.80 , stations 1 and 2 being those that presented the greater values, followed by station 3 and station 5 ; station 4 was the one with the smallest eveness (Figs 5 and 6). As for richness, stations 1 and 2 were those that presented the greatest values, followed by station 5 and, at last, by stations 3 and 4 (Figs 7 and 8). The estimation above may have a bias due to the different number of individuals collected in each station, for which reason rarefaction was used. The standardized richness by rarefaction for 250 individuals shows that stations 1, 2 and 5 were the ones that presented the greatest richness (Fig. 9). In general, the number of collected individuals was greater in the dry than in rainy, except at station 4 (Fig. 9). Results showed that, when the same number of individuals is considered, richness did not vary between the two seasons (Fig. 9).

Table II. Immatures of EPT genera collected from June 1993 to July 1994 in five stations in streams of the Serra dos Pireneus, Pirenópolis.

\begin{tabular}{|c|c|c|c|c|c|c|}
\hline \multirow{2}{*}{ Taxons } & \multicolumn{5}{|c|}{ Stations } & \multirow{2}{*}{$\mathrm{N}$} \\
\hline & 1 & 2 & 3 & 4 & 5 & \\
\hline \multicolumn{7}{|l|}{ Ephemeroptera } \\
\hline \multicolumn{7}{|l|}{ Baetidae } \\
\hline Baetis s.l. Leach, 1815 & $x$ & $x$ & $x$ & $x$ & $x$ & 662 \\
\hline Aff. Bernerius Waltz \& McCafferty, 1987 & $x$ & $x$ & $x$ & $x$ & $x$ & 83 \\
\hline Camelobaetidius Demoulin, 1966 & & $x$ & $x$ & $x$ & $x$ & 130 \\
\hline \multicolumn{7}{|l|}{ Euthyplociidae } \\
\hline Campylocia Needham \& Murphy, 1924 & $\mathrm{x}$ & & & & & 28 \\
\hline \multicolumn{7}{|l|}{ Leptohyphidae } \\
\hline Leptohyphes Eaton, 1882 & $\mathrm{X}$ & $x$ & $x$ & $x$ & $x$ & 821 \\
\hline \multicolumn{7}{|l|}{ Leptophlebiidae } \\
\hline Aff. Dactylophlebia Pescador \& Peters, 1980 & & $\mathrm{x}$ & & & & 2 \\
\hline Aff. Demoulinellus Pescador \& Peters, 1982 & $\mathrm{x}$ & $\mathrm{x}$ & $\mathrm{X}$ & & & 6 \\
\hline Farrodes Peters, 1971 & $\mathrm{X}$ & $\mathrm{X}$ & & $x$ & $x$ & 13 \\
\hline Hermanella Needham \& Murphy, 1924 & & & & $\mathrm{x}$ & & 2 \\
\hline Hylister Dominguez \& Flowers, 1989 & $x$ & $\mathrm{x}$ & $x$ & & & 12 \\
\hline Massartella Lestage, 1930 & $x$ & & & & & 123 \\
\hline Needhanmella Dominguez \& Flowers, 1989 & $x$ & $x$ & $x$ & $x$ & $x$ & 81 \\
\hline Aff. Nousia Navás, 1918 & $x$ & $\mathrm{x}$ & $x$ & $x$ & $x$ & 118 \\
\hline Thraulodes Ulmer, 1920 & $x$ & $x$ & $x$ & $x$ & $x$ & 144 \\
\hline Traverella Edmunds, 1948 & & & & & $x$ & 3 \\
\hline \multicolumn{7}{|l|}{ Oligoneuriidae } \\
\hline Lachlania Hagen, 1868 & & & & $x$ & & 3 \\
\hline
\end{tabular}


Table II. Continued.

\begin{tabular}{|c|c|c|c|c|c|c|}
\hline \multirow{2}{*}{ Taxons } & \multicolumn{5}{|c|}{ Stations } & \multirow{2}{*}{$\mathrm{N}$} \\
\hline & 1 & 2 & 3 & 4 & 5 & \\
\hline \multicolumn{7}{|l|}{ Plecoptera } \\
\hline \multicolumn{7}{|l|}{ Gripopterygidae } \\
\hline Gripopteryx Pictet, 1841 & $x$ & & & & & 16 \\
\hline Tupiperla Froehlich, 1969 & $x$ & & & & & 13 \\
\hline \multicolumn{7}{|l|}{ Perlidae } \\
\hline Anacroneuria Klapálek, 1909 & $x$ & $x$ & $x$ & $x$ & $x$ & 858 \\
\hline Kempnyia Klapálek, 1914 & $x$ & $x$ & & & $x$ & 30 \\
\hline Macrogynoplax Enderlein, 1909 & $x$ & & & & $x$ & 17 \\
\hline \multicolumn{7}{|l|}{ Trichoptera } \\
\hline \multicolumn{7}{|l|}{ Calamoceratidae } \\
\hline Phylloicus Müller, 1880 & $x$ & $x$ & $x$ & & $x$ & 135 \\
\hline \multicolumn{7}{|l|}{ Glossosomatidae } \\
\hline Protoptila Banks, 1904 & $x$ & $x$ & $x$ & $x$ & $x$ & 552 \\
\hline \multicolumn{7}{|l|}{ Hydrobiosidae } \\
\hline Atopsyche Banks, 1905 & $x$ & $x$ & $x$ & $x$ & $x$ & 144 \\
\hline \multicolumn{7}{|l|}{ Helicopsychidae } \\
\hline Helicopsyche Siebold, 1856 & $x$ & $x$ & $x$ & & $x$ & 87 \\
\hline \multicolumn{7}{|l|}{ Hydropsychidae } \\
\hline Leptonema Guérin, 1843 & $x$ & $x$ & $x$ & $x$ & $x$ & 639 \\
\hline Macronema Pictet, 1836 & $x$ & & $x$ & & $x$ & 27 \\
\hline Smicridea McLachlan, 1871 & $x$ & $x$ & $x$ & $x$ & $x$ & 498 \\
\hline \multicolumn{7}{|l|}{ Hydroptilidae } \\
\hline Hydroptila Dalman, 1819 & & & $x$ & & $x$ & 9 \\
\hline Dicaminus Müller, 1879 & & $x$ & & & & 4 \\
\hline Oxyethira Eaton, 1873 & $x$ & $x$ & & & $x$ & 14 \\
\hline \multicolumn{7}{|l|}{ Leptoceridae } \\
\hline Atanatolica Mosely, 1936 & $x$ & $x$ & $x$ & & & 7 \\
\hline Grumichella Müller, 1879 & & $x$ & $x$ & & $x$ & 136 \\
\hline Nectopsyche Müller, 1879 & $x$ & $x$ & & $x$ & $x$ & 54 \\
\hline Oecetis McLachlan, 1877 & $x$ & $x$ & $x$ & $x$ & $x$ & 82 \\
\hline \multicolumn{7}{|l|}{ Odontoceridae } \\
\hline Barypenthus Burmeister, 1839 & $x$ & $x$ & & & & 108 \\
\hline Marilia Müller, 1880 & $x$ & $x$ & & & $x$ & 100 \\
\hline \multicolumn{7}{|l|}{ Philopotamidae } \\
\hline Chimarra Stephens, 1829 & $x$ & $x$ & $x$ & $x$ & $x$ & 409 \\
\hline \multicolumn{7}{|l|}{ Polycentropodidae } \\
\hline Polycentropus Curtis, 1835 & & & & & $x$ & 6 \\
\hline \multicolumn{7}{|l|}{ Xiphocentronidae } \\
\hline Xiphocentron Brauer, 1870 & $x$ & & $x$ & $x$ & & 20 \\
\hline Genus Number & 31 & 28 & 23 & 19 & 27 & \\
\hline Total of Ephemeroptera nymphs & 268 & 516 & 821 & 239 & 387 & 2231 \\
\hline Total of Plecoptera nymphs & 286 & 221 & 93 & 22 & 312 & 934 \\
\hline Total of Trichoptera larvae & 425 & 901 & 843 & 435 & 427 & 3031 \\
\hline Total & 979 & 1638 & 1757 & 696 & 1126 & 6196 \\
\hline
\end{tabular}



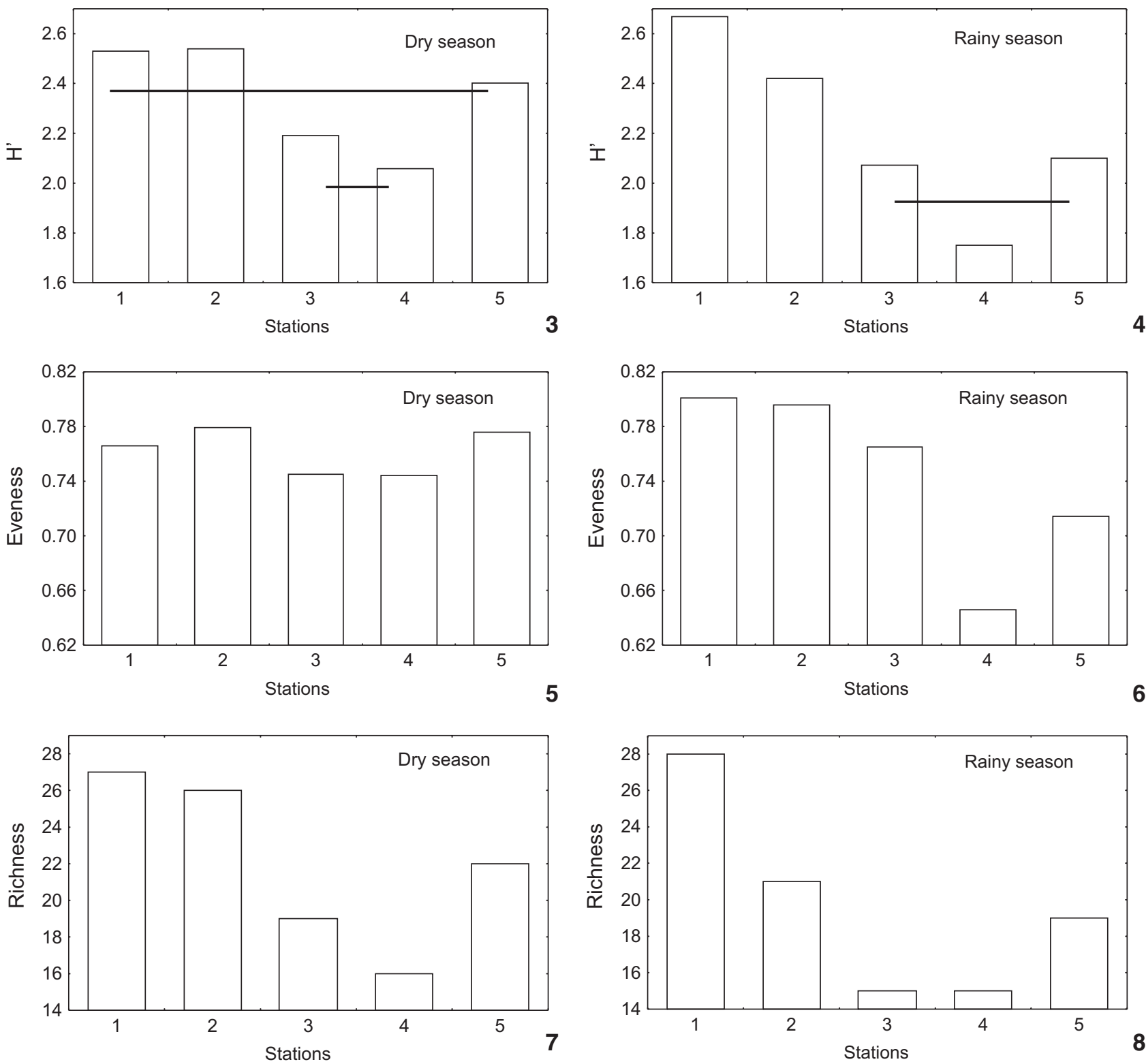

Figures 3-8. Diversity and richness of immatures of genera of EPT in five stations in streams of the Serra dos Pireneus, Pirenópolis. The stations linked by the line (Figs $3 a$ and $3 b)$ showed no significative differences, $t$ test of Hutcheson with Bonferroni correction $(\alpha / 10=$ 0.005). Dry season (June-November); rainy season (December-May).

\section{Spatial and Temporal Structure of EPT Fauna}

A two factors ANOSIM without replication was applied in order to check whether there was modification in the multivariate structure under spatial and temporal points of view. Both variation sources were important for the organization of the EPT fauna, the source of spatial variation $(\rho=0.467 ; \mathrm{p}<$ 0.001 for 1000 permutations) and the source of temporal variation ( $\rho=0.221 ; \mathrm{p}<0.001$ for 1000 permutations) (Tab. III).
Table III. Results of the ANOSIM two factors without replication considering the sources of spatial and temporal variation of the EPT assemblages collected from June 1993 to July 1994 in five stations in streams of the Serra dos Pireneus, Pirenópolis.

\begin{tabular}{lccc}
\hline Factors & Global $\rho$ (observed) & Number of permutations & $p$ \\
\hline Spatial & 0.467 & 1000 & 0.001 \\
Temporal & 0.221 & 1000 & 0.001 \\
\hline
\end{tabular}



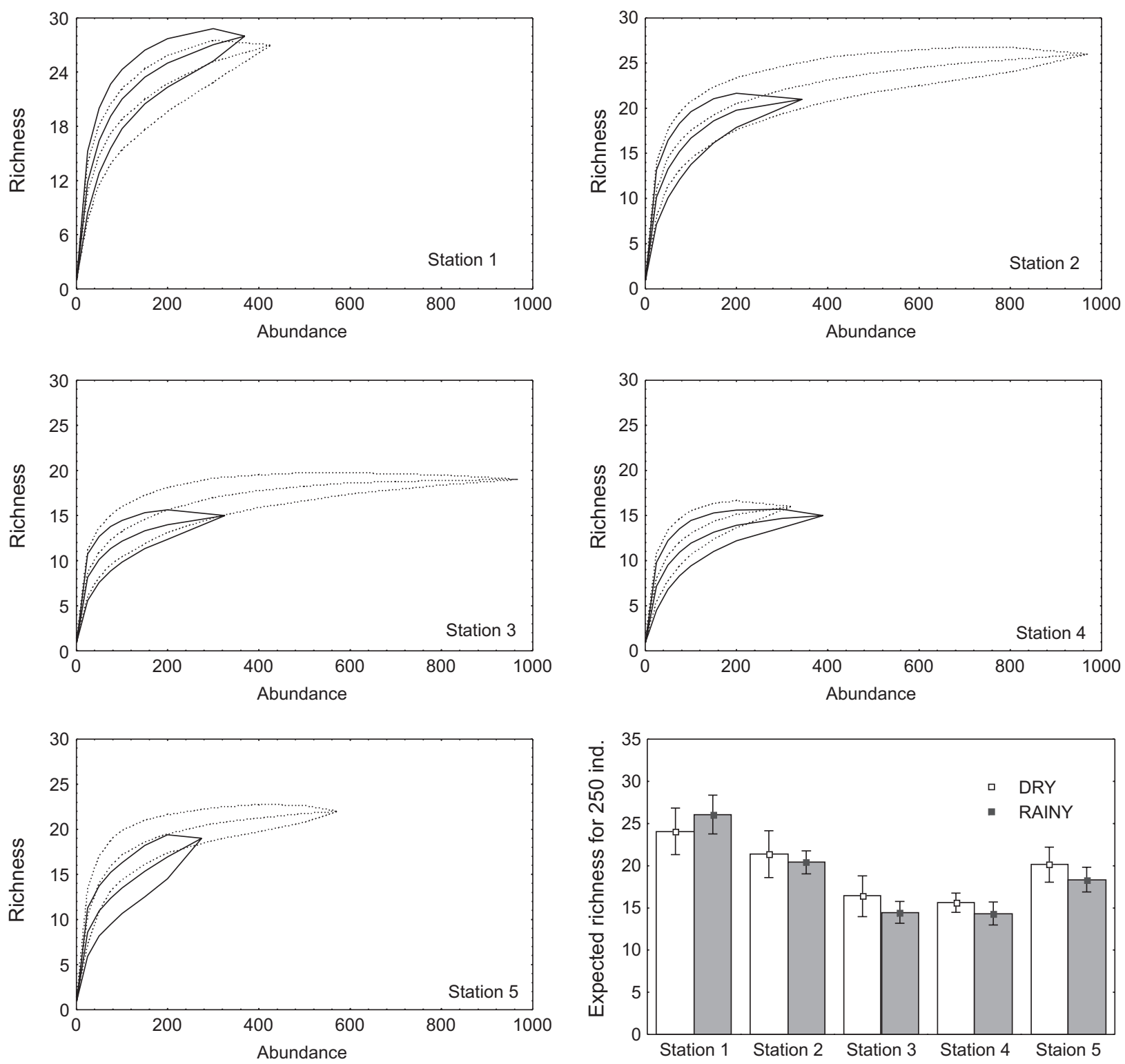

Figure 9. Rarefaction curves of immatures of genera of EPT collected in five stations in streams of the Serra dos Pireneus, Pirenópolis. Dashed line, dry season; continuous line, rainy season. Dry season (June-November); rainy season (December-May).

The dispersion of samples in two dimensions space, according to DCA, is presented in figure 10 . The first axis $(47.2 \%$ of the variance) separated part of the samples collected in the different streams. The samples of streams with lower flow (stations 1 and 5) tended to have greater scores, however, part of the scores of station 5 overlapped with scores of higher order stations. The scores of station 1 were always higher than those of station 5 . The smaller scores were from samples collected in segments of higher order (stations 2, 3 and 4). Considering the first axis of DCA, temporal variability (represented by the stan- dard deviation) was similar among the scores of the different stations. When the second axis (13.7\% of the variance) was considered, there was greater temporal variability of the scores of the larger streams (Fig. 11).

TWINSPAN demonstrated that the structure of EPT communities was modified temporally, and many samples of the same station overlapped with samples from other stations at different times of the studied period (Fig. 12). The first level of dichotomy of TWINSPAN separated all the samples of station 1 together with two samples of station 5 (one collected in the dry 

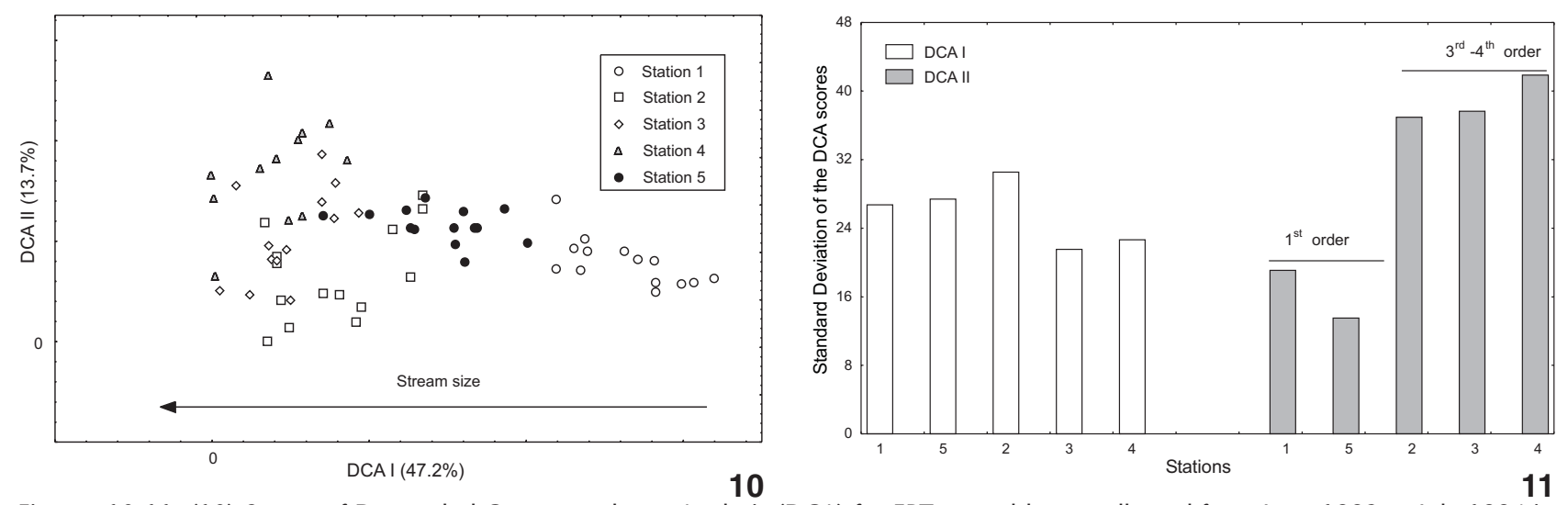

Figures 10-11. (10) Scores of Detrended Correspondence Analysis (DCA) for EPT assemblages collected from June 1993 to July 1994 in five stations in streams of the Serra dos Pireneus, Pirenópolis; (11) Standard deviation of the scores corresponding to the first two DCA axes for EPT assemblages collected from June 1993 to July 1994 in five stations in streams of the Serra dos Pireneus, Pirenópolis.

season and the other, in the rainy season) (group III). The second level of dichotomy separated groups I and II. Group I comprised the majority of the samples from stations 2,3 and 4 , collected during dry season and group II comprised the majority of samples from station 2, 3 and 4, collected in the rainy season, together with most samples collected at station 5 (Fig. 12).

\section{DISCUSSION}

\section{EPT Diversity}

Patterns of abundance, richness and diversity vary under different spatial and temporal scales. Input of energy, environmental heterogeneity, environmental disturbance and biotic interactions are important elements in determining the diversity of macroinvertebrate communities in lotic environments (Vannote et al. 1980, Hildrew \& Towsend 1987, Mccabe \& Gotelli 2000, Voelz \& McArthur 2000). In this work it was observed that the standardized EPT richness of Pirenópolis was intermediate when compared to the richer fauna of Campos do Jordão (Oliveira \& Froenlich 1997, Fig. 2), and the poorer fauna of Parque Estadual Intervales (Fig. 2). Richness of aquatic invertebrates may change with the increase of stream size as a reaction to longitudinal changes (VANNote et al. 1980, Minshall et al. 1985, Melo \& Froenlich 2001). We observed that the standardized richness of EPT fauna was greater in $1^{\text {st }}$ order, sites if compared to $3^{\text {rd }}$ and $4^{\text {th }}$ order streams. Data for the EPT fauna of Campos do Jordão (Oliveira \& Froehlich 1997, Fig. 2) showed a standardized richness slightly greater in $1^{\text {st }}$ order streams than in $3^{\text {rd }}$ order ones and data for Parque Estadual Intervales (Fig. 2) showed a similar standardized richness between streams of $1^{\text {st }}-2^{\text {nd }}$ orders and $3^{\text {rd }}-4^{\text {th }}$ orders. These data demonstrate that the highest richness in $1^{\text {st }}-2^{\text {nd }}$ orders streams (low orders) observed in this study is not a general pattern to EPT data.

Nowadays, anthropic influence is one of the factors that most interferes in richness and diversity of aquatic insects
(Rosenberg \& Resh 1993, Zamora-Muñoz \& Alba-Tercedor 1996, Shieh et al. 1999, Moore \& Palmer 2005). In disturbed streams, a decrease of sensitive taxa and an increase in importance of tolerant taxa is expected, reducing the diversity. This study confirms this assumption since the sites with greater anthropic impact, stations 3 (country club) and 4 (Pirenópolis town) presented clearly smaller values for richness and Shannon-Wiener diversity index when compared to the stations with better environmental conditions (stations 1, 2 and 5). Nevertheless, in the rainy season, the value of the Shannon-Wiener index of station 3 (disturbed site) was similar to the value of station 5 (good environmental condition). In this case, the similar diversity between two stations with different environmental conditions in the rainy season could be explained by a possible redistribution of aquatic insects provoked by spates (BISPO et al. 2006) that could disorder the spatial patterns of EPT distribution and diversity (Bispo \& Oliveira 1998, Diniz-Filho et al. 1998). Station 4, located in Pirenópolis town, the site with the greatest anthropic action, had smaller values of richness and of diversity. The EPT fauna is very sensitive to environmental disturbances (ROSENBERG \& Resh 1993); in this work it was observed that the anthropic action observed in some stations, although relatively small when compared with other regions, was an important factor in the decrease of richness and diversity of the EPT fauna.

We have observed, in this study, that the standardized richness of EPT taxa (rarefaction method) was greater in stations 1, 2 and 5 in relation to stations 3 and 4, which confirms the effect of anthropic action over that attribute. In general, the standardized richness did not differ between both seasons for the same station. Therefore, the differences of richness observed between both seasons, before standardization, may be considered only a product of the greater number of individuals collected in the dry season. That pattern may be due to the smaller intensity and lesser frequency of disturbances, and to 


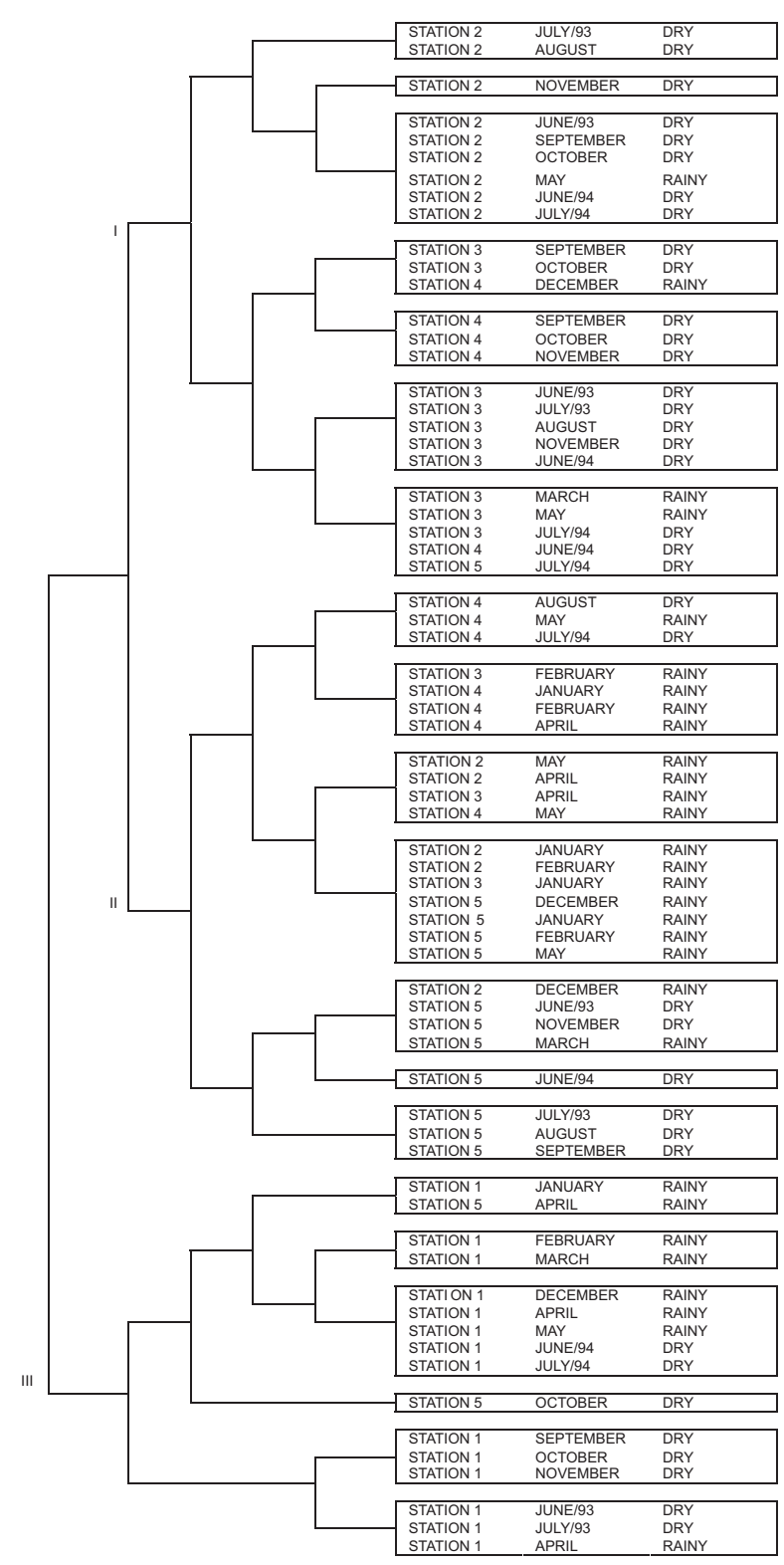

Figure 12. Divisive dendrogram (TWINSPAN) obtained with EPT assemblages collected from June 1993 to July 1994 in five stations in streams of the Serra dos Pireneus, Pirenópolis. Pseudospecies cut levels, 0, 2, 5, 10 and 20.

the increase in aggregation of the fauna in this season according to Bispo et al. (2006).

\section{Spatial and Temporal Structure of EPT Fauna}

Spatial and temporal variability of environmental factors may determine the organization of communities of aquatic insects (BAPTISTA et al. 2001). In this study, both spatial and temporal sources of variation were important for the structuring of the
EPT fauna (Tab. III). According to DCA I, the scores representative of the samples collected in $1^{\text {st }}$ order streams tended to have greater values than those of samples collected in sites of $3^{\text {rd }}$ and $4^{\text {th }}$ orders. Therefore, stream size and factors related to it were important for structuring the EPT fauna (BisPo et al. 2006). It is important to highlight that subjacent to variation in stream size are the changes in the predominant inputs of energy, the daily variation of temperature and hydraulics (VANNOTE et al. 1980, StATZner \& Higler 1986). DCA I results show that there is, from the spatial point of view, a gradient of EPT fauna from low to medium order stations, which indicates that local factors were important determinants in the faunal structure.

During the period of study, field observations showed that the sites with smaller flow (stations 1 and 2) were more stable environments, as sudden increases in flow provoked smaller perturbations than the great and quick increases in flow observed in rainy days at the larger sites (stations 2, 3 and 4). Based on this observation, it would be expected the EPT fauna to show a larger temporal variability in streams of larger order. The data of this study confirm such assumption since, when considering the second DCA axis, temporal variability of the fauna (represented by the standard deviation of the scores) was clearly smaller in the stations with lower flow (stations 1 and 5) in relation to those with larger flow (stations 3, 4 and 5) (Fig. 11).

The spatial variability of environmental variables in different scales is an important factor, which determines the organization of the communities of aquatic organisms in lotic environments. So, it is expected that the samples collected in the same site, in different periods of the year, would be more similar among themselves than the samples collected in other sites, though such assumption may not be confirmed in a highly seasonal environment. JACOBSEN \& ENCALADA (1998), when studying highly seasonal streams in Ecuador, did not register very similar samples from the same station in two seasons (dry and rainy). In the present study, which also took place in a highly seasonal environment with very defined dry and rainy seasons, part of the samples collected in stations 2, 3, 4 and 5 was grouped in group I and the other part in group II (TWINSPAN, Fig. 12). So, the samples collected in those four stations grouped together in two different groups, independently of the station. This pattern could be explained by the high environmental seasonality of the cerrado biome, that is, the seasonal variability can conceal the effect of spatial variability on the faunal structure. The exception was station 1, whose samples, collected in different periods of the year, formed a group; this pattern, according to BISPO et al. (2006), was mainly due to the presence of taxa characteristic of higher altitudes that made up a distinctive fauna. In a general manner, from the spatial point of view, data of the present work showed that anthropic influence determined the patterns of diversity while the size of streams ( $1^{\text {st }}$ and $3^{\text {rd }}-4^{\text {th }}$ orders) determined the faunistic composition. Seasonality was also an important factor in structuring the EPT fauna. 


\section{ACKNOWLEDGMENTS}

We are indebted to FUNAPE for support for field collecting, to FAPESP (process 98/11074-3; 02/07216-4; 04/09711-8) and CNPq (process 473246/2004-0) for their financial support to PCB. PCB (process 301578/2004-4) and LGO (proc. 300833/ 1998-9) are CNPq researchers of productivity. We also thank Claudio G. Froehlich and Vera Lúcia Crisci Bispo for a critical reading of the manuscript.

\section{REFERENCES}

AngrisAno, E.B. 1995. Insecta Trichoptera, p. 1199-1224. In: E.C. Lopretto \& G. Tell (Eds). Ecosistemas de aguas continentales. Metodologias para su estudio. La Plata, Ediciones Sur, vol. 3, p. 897-1401.

Baptista, D.F.; L.F. Dorvillé; D.F Buss \& J.L. Nessimian. 2001. Spatial and temporal organization of aquatic insect assemblages in the longitudinal gradient of a tropical river. Brazilian Journal of Biology 61 (2): 295-304.

Benedetto, L. 1974. Clave para la determinación de los plecopteros sudamericanos. Studies on Neotropical Fauna and Environment 9: 141-170.

Bispo, P.C. \& L.G. Oliveira. 1998. Distribuição espacial de insetos aquáticos (Ephemeroptera, Plecoptera e Trichoptera), em córregos de cerrado do Parque Ecológico de Goiânia, Estado de Goiás, p. 175-189. In: J.L. Nessimian \& A.C. Carvalho (Eds). Ecologia de insetos aquáticos. Rio de Janeiro, Série Oecologia Brasiliensis, PPGE-UFRJ, vol. 5, XVII+309p.

Bispo, P.C.; L.G. Oliveira; L.M. Bini \& K.G. Sousa. 2006. Ephemeroptera, Plecoptera and Trichoptera form riffles in mountain streams of Central Brazil: environmental factors influencing the distribution and abundance of immatures. Brazilian Journal of Biology 66 (2B): 611-622.

Clarke, K.R. \& R.M. Warwick. 1994. Change in Marine Communities: An Approach to Statistical Analysis and Interpretation. Plymouth, Plymouth Marine Laboratory, $144 \mathrm{p}$.

Clarke, K.R. \& R.N. Gorley. 2001. PRIMER v5: User manual/ tutorial. Plymouth, Primer-E Ltd.

Diniz-Filho, J.A.F.; L.G. Oliveira \& M.M. Silva. 1998. Explaining the beta diversity of aquatic insects in "cerrado" streams from Central Brazil using multiple Mantel Test. Revista Brasileira de Biologia 58 (2): 223-231.

Domínguez, E.; M.D. Hubbard \& W.L. Peters. 1992. Clave para ninfas y adultos de las familias y géneros de Ephemeroptera (Insecta) sudamericanos. La Plata, NLPCONICET, Biología Acuática 16, 32p.

Flecker, A.S. \& B. Feifarek. 1994. Disturbance and temporal variability of invertebrate assemblages in two Andean streams. Freshwater Biology 31: 131-142.

Froenlich, C.G. 1984. Brazilian Plecoptera 4. Nymphs of perlid genera from southeastern Brazil. Annales de Limnologie 20 (1-2): 43-48.
GaUCH, H.G. JR. 1995. Multivariate Analysis in Community Ecology. Cambridge, Cambridge University Press, VIII+298p.

Gotelli, N.J \& A.M. Ellison. 2004. A Primer of Ecological Statistics. Sunderland, Sinauer Associates, XVIII+510p.

Gotelli, N.J. \& G.L. Entsminger. 2000. EcoSim: null models software for ecology. Version 5.0, Acquired Intelligence Inc. $\&$ Kesey-Bear. Available in the World Wide Web at: http:// homepages.together.net/ gentsmin/ecosim.htm [Acessed in 02.II.2002]

Hildrew, A.G. \& C.R. Townsend. 1987. Organization in Freshwater Benthic Communities, p. 347-371. In: J.H.R. GeE \& P.S. GILLER (Eds). Organization of communities: past and present. Oxford, Blackwell Scientific Publications, 576p.

Hulbert, S.H. 1971. The nonconcept of species diversity: a critique and alternative parameters. Ecology 52: 577-585.

Lind, O.T. 1979. Handbook of Common Methods in Limnology. London, C.V. Mosby Company, XI+199p.

JACOBSEn, D. \& A. ENCALADA. 1998. The macroinvertebrate fauna of Ecuadorian high-land streams in wet and dry season. Archiv für Hydrobiologie 142 (1): 53-70.

Magurran, A.E. 1989. Ecological Diversity and It's Measurement. London, Chapmam \& Hall, X+179p.

Marchant, R; L.A. Barmuta \& B.C. Chessman. 1995. Influence of sample quantification and taxonomic resolution on the ordination of macroinvertebrate communities from running waters in Victoria, Australia. Marine \& Freshwater Research 46: 501-506.

McCabe, D.J. \& N.G. Gotelli, 2000. Effects of disturbance frequency, intensity, and area on assemblages of stream macroinvertebrates. Oecologia 124: 270-279.

McCune, B. \& M.J. Mefford. 1999. PC-ORD. Multivariate analysis of ecological data. Version 4.0. Gleneden Beach, Oregon, MjM Software Design.

Melo, A.S. \& C.G. Froehlich. 2001. Macroinvertebrates in neotropical streams: richness patterns along a catchment and assemblage structure between 2 seasons. Journal of the North American Benthological Society 20 (1): 1-16.

Minshall, G.W.; R.C. Petersen \& C.F. Nimz. 1985. Species richness in streams of different size from the same drainage basin. American Naturalist 125 (1): 16-38.

Moore, A.A \& M.A. Palmer. 2005. Invertebrate biodiversity in agricultural and urban headwater streams: implications for conservation and management. Ecological Applications 15 (4): 1169-117.

NIMER, E. 1989. Climatologia do Brasil. Rio de Janeiro, IBGE, $421 \mathrm{p}$.

Oliveira, L.G. \& C.G. Froenlich. 1997. Diversity and community structure of aquatic insects (Ephemeroptera, Plecoptera and Trichoptera) in a mountain stream in Southeastern Brazil. Acta Limnologica Brasiliensia 9: 139-148.

Richards, C.; G.E. Host \& J.W. Arthur. 1993. Identification of predominant environmental factors structuring stream macroinvertebrate communities within a large agricultural 
catchment. Freshwater Biology 29: 285-294.

Rosenberg, D.M. \& V.H. Resh. 1993. Freshwater biomonitoring and benthic macroinvertebrates. London, Chapman \& Hall, IX + 488p.

Simberloff, D. 1972. Properties of the rarefaction diversity measurement. The American Naturalist 106: 414-418.

Shieh, S.H.; B.C. KondratiefF; J.V. Ward \& D.A. Rice. 1999. The relationship of macroinvertebrate assemblages to water chemistry in a polluted Colorado plains stream. Archiv für Hydrobiologie 145 (4): 405-432.

Statzner, B. \& B. Higler. 1986. Stream hydraulics as a major determinant of benthic invertebrate zonation patterns. Freshwater Biology 16: 127-139.

Strahler, H.N. 1957. Quantitative analysis of watershed geomorphology. American Geophysics Union Transactions 33: 913-920.

Vannote, R.L.; G.W. Minshall; K.W.L. Cummins; J.R. Sedell \& C.E.
Cushing. 1980. The River Continuum Concept. Canadian Journal of Fisheries and Aquatic Sciences 37: 130-137.

Voeltz, N.J. \& J.V. McArthur. 2000. An exploration of factors influencing lotic insect species richness. Biodiversity Conservation 9: 1543-1570.

Wiggins, G.B. 1998. Larvae of the North America caddis fly genera (Trichoptera). Toronto, University of Toronto Press, $2^{\text {nd }}$ ed., IX+457p.

Zamora-Muñoz, C. \& J. Alba-Tercedor. 1996. Bioassessment of organically polluted Spanish rivers, using a biotic index and multivariate methods. Journal of North American Benthological Society 15: 332-352.

Zamora-Muñoz, C.; A. Sanchez-Ortega \& J. Alba-Tercedor. 1993. Physico-chemical factors that determine the distribution of mayflies and stoneflies in a high-mountain stream in southern Europe (Sierra Nevada, Southern Spain). Aquatic Insects 15: 11-20.

Received in 16.VIII.2006; accepted in 26.IV.2007. 